\title{
ОСОБЛИВОСТІ ФОРМУВАННЯ ТА ДИНАМІКИ РОЗВИТКУ ЗУБНОГО РЯДУ ВЕРХНЬОЇ ЩЕЛЕПИ У ПАЦІЕНТІВ ІЗ ДВОБІЧНИМИ ПРИРОДЖЕНИМИ НАСКРІЗНИМИ НЕЗРОЩЕННЯМИ ВЕРХНЬОЇ ГУБИ ТА ПІДНЕБІННЯ ПІСЛЯ ОПЕРАЦЙНИХ ВТРУЧАНЬ
}

Львівський національний медичний університет імені Данила Галицького

\begin{abstract}
Резюме. Проведено аналіз 33 діагностичних контрольних моделей в оперованих пацієнтів із наскрізними двобічними природженими незрощеннями верхньої губи та піднебіння, визначено ширину зубного ряду верхньої щелепи та довжину фронтальної ділянки верхньої щелепи і порівняно їх з нормою. Виявлені характерні особливості деформацій зубного ряду верхньої ще-
\end{abstract}

Вступ. Серед усіх уроджених дефектів і деформацій щелепно-лицевої ділянки найбільш поширеними є природжені незрощення верхньої губи та піднебіння (ПНВГП), які посідають друге місце серед усіх уроджених вад новонароджених [1], при цьому тенденції до їх зниження не спостерігається $[4,11]$. Актуальність проблеми комплексного лікування пацієнтів із ПНВГП зумовлена глибокими морфологічними і функціональними порушеннями зубощелепного комплексу, які відносяться до таких, що тяжко лікуються. Естетичні порушення обличчя, які виникають як до, так і після відновних оперативних втручань, обмежують спілкування людини в товаристві, пригнічують іiі свідомість поняттям фізичної неповноцінності і призводять до депресій психічного стану. Клінічні спостереження демонструють, що природжені незрощення верхньої губи і піднебіння призводять до зупинки розвитку верхньої щелепи, і це сприяє утворенню тяжких аномалій прикусу, зубних рядів і розташування окремих зубів $[5,6]$. Тому важливо якомога точніше здійснити прогноз можливих змін з боку лицевого скелета в кожному віковому періоді залежно від виду незрощення, а основним завданням клінічного етапу лікування $є$ створення оптимальної анатомічної форми верхньої зубної дуги. Саме тому важливим $\epsilon$ визначення особливостей формування верхнього зубного ряду в пацієнтів із природженими незрощеннями верхньої губи та піднебіння в післяопераційному періоді залежно від видів незрощення.

Мета дослідження. Вивчити динаміку формування та особливостей деформацій зубного ряду верхньої щелепи у віковому аспекті пацієнтів 3 двобічним ПНВГП після оперативнопластичних втручань.

Матеріал і методи. У 23 обстежених пацієнтів (12 чоловіків і 11 жінок), які раніше перенесли операційні втручання 3 приводу двобічного ПНВГП, отримані 33 контрольні моделі верхньої та нижньої щелеп з визначенням і фіксацією, за необхідності, центральної оклюзії 3 подальшим гіпсуванням моделей в оклюдаторі [3]. Розподіл

(c) А.Ю. Олійник , 2015

126 лепи та динаміка їх формування, які обов'язково повинні бути враховані при наданні ортодонтичної допомоги цим хворим та виборі відповідних ортопедичних конструкцій для їх адекватного протезування.

Ключові слова: природжені незрощення піднебіння, деформації верхніх зубних рядів.

моделей за статтю і віком та станом прикусу пацієнтів за Ф.Я. Хорошилкиной [6] поданий у таблиці 1.

Аналіз діагностичних моделей включав: загальну оцінку стану зубощелепної системи пацієнта; математичне визначення симетричності (або асиметрії) правої і лівої частин зубного ряду залежно від віку, статі та видів незрощення верхньої щелепи; вивчення ширини зубних рядів за Поном [10] (A. Pont,) у порівнянні з показниками норми, розрахованими за A. Pont 3 поправкою H. Linder i G. Hart. За відсутності на верхній щелепі чотирьох різців за відправну величину бралася сума чотирьох різців нижньої щелепи з поправками Tonn; визначення довжини фронтальної ділянки верхньої щелепи за методом Коркхауза (G. Korkhaus) [8]. Усі цифрові величини уведені у програму для статистичного аналізу SPSS 13. Статистично значимим результат був визнаний за умови, що $\mathrm{p}<0,05$. За визначеними середніми величинами побудовані графічні зображення стану верхньої щелепи пацієнтів після оперативних втручань 3 приводу незрощення верхньої губи і піднебіння, залежно від видів незрощення, віку та статі.

Результати дослідження та їх обговорення. Визначення ширини зубних рядів верхньої щелепи чоловіків із двобічним ПНВГП за Поном проведено у віковому діапазоні від 7 до 22 років (табл. 2). 3 метою наочності динаміки змін ширини зубних рядів верхньої щелепи у віковому аспекті за середньостатистичними величинами побудовані графіки в масштабі 1 мм=10 мм (рис. 1) порівняно $з$ нормою. Аналогічні розрахунки здійснені за вимірюванням контрольних моделей верхньої щелепи в осіб жіночої статі (табл. 3, рис. 2). Важливим чинником у визначенні формування деформацій зубного ряду верхньої щелепи в пацієнтів із ПНВГП є не тільки факт констатації загального зменшення чи збільшення ширини зубного ряду в різні вікові періоди, але й визначення - за рахунок якого саме фрагмента незрощеної верхньої щелепи відбуваються такі зміщення $[2,9]$.

Ширина зубного ряду на рівні $4 \mid 4$ зубів у 9 , 14 та 16 років була меншою порівняно з нормою: 
Таблиця 1

Розподіл отриманих діагностичних моделей відповідно до статі і віку обстежених хворих із двобічним незрощенням піднебіння

\begin{tabular}{|c|c|c|c|}
\hline \multirow{2}{*}{ Вік і стан прикусу } & \multicolumn{2}{|c|}{ Стать } & \multirow{2}{*}{ Всього } \\
\cline { 2 - 3 } 6-8 років & Ч (n) & Ж (n) & 2 \\
\hline $\begin{array}{c}\text { 9-12 років } \\
\text { Пізній змінний прикус }\end{array}$ & 3 & 1 & 8 \\
\hline $\begin{array}{c}\text { 13-18 років } \\
\text { Формування постійного прикусу }\end{array}$ & 10 & 6 & 16 \\
\hline $\begin{array}{c}19-24 \text { роки } \\
\text { Доформовування постійного прикусу }\end{array}$ & 4 & 2 & 6 \\
\hline $\begin{array}{c}25 \text { років і> }> \\
\text { Сформований постійний прикус }\end{array}$ & 0 & 1 & 1 \\
\hline Всього & 18 & 15 & 33 \\
\hline
\end{tabular}

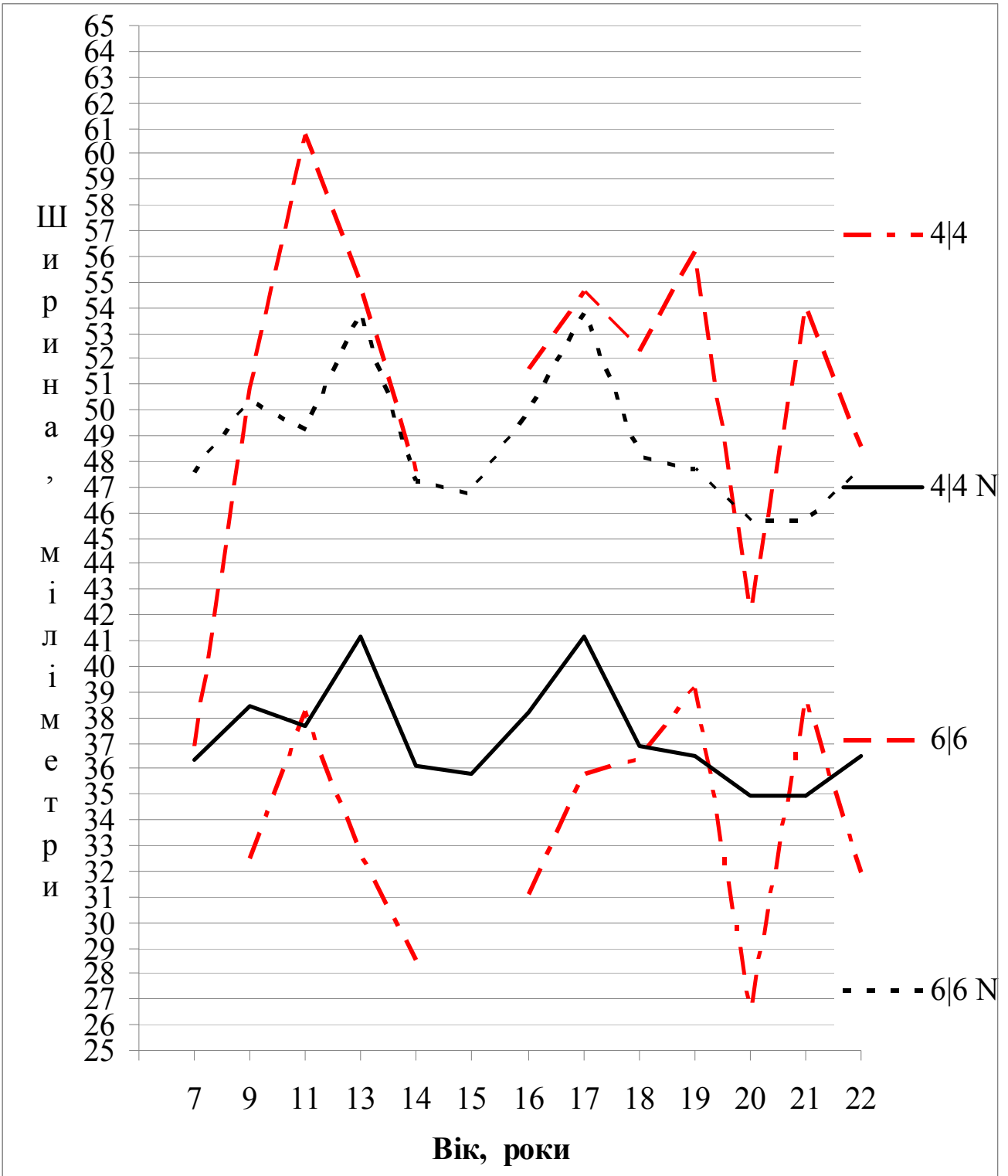

Рис. 1. Графічне зображення динаміки змін ширини зубного ряду верхньої щелепи чоловіків із двобічним природженим незрощенням верхньої губи та піднебіння за віком 


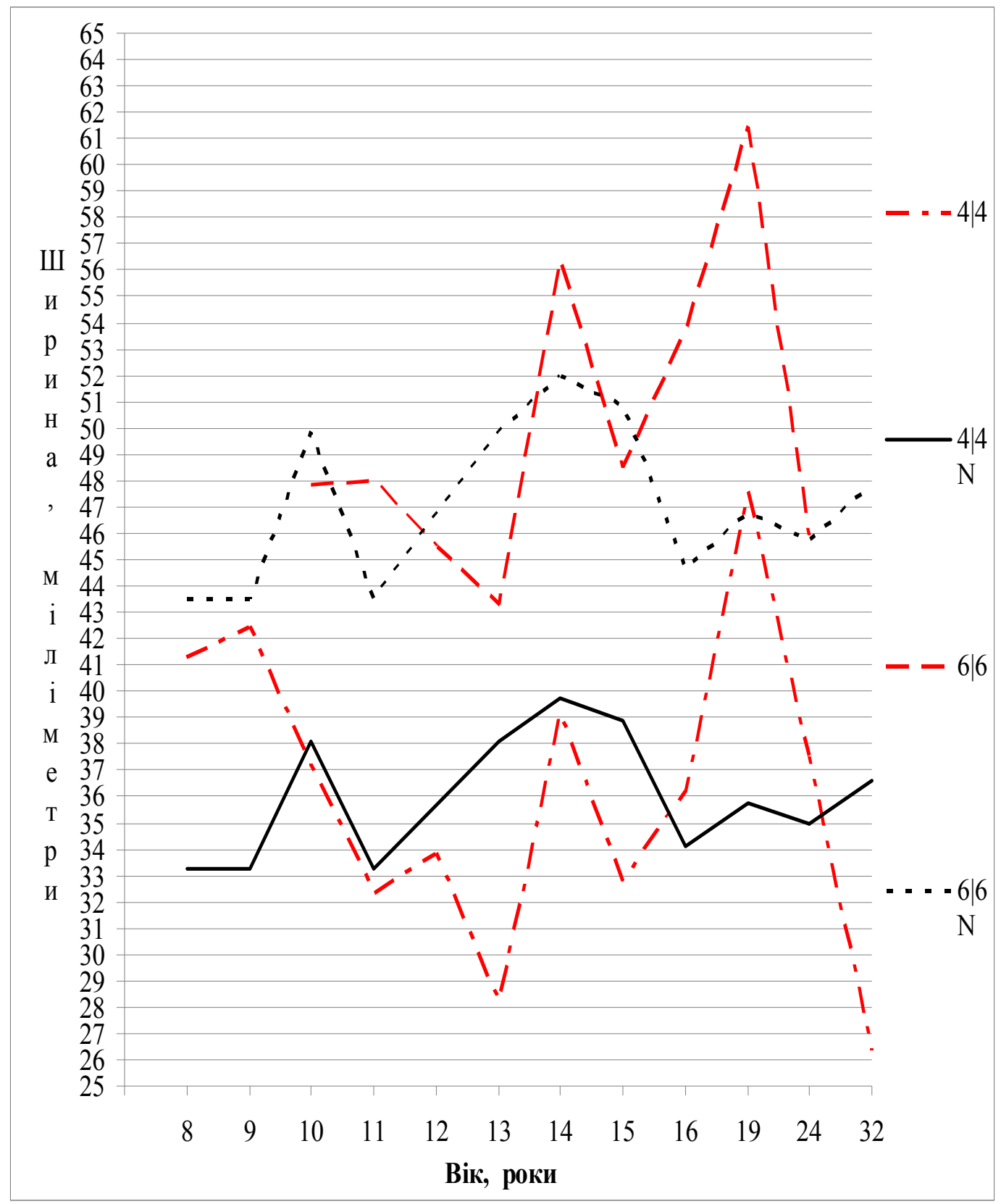

Рис. 2. Графічне зображення динаміки змін ширини зубного ряду верхньої щелепи жінок із двобічним природженим незрощенням верхньої губи та піднебіння за віком

9 років - 32,45 $\pm 1,54$ проти норми $38,47 \pm 2,71 ; 14$ років - 28,51 $\pm 3,24$ проти норми $36,12 \pm 0,36 ; 16$ років - 31,06 $\pm 4,91$ проти норми $38,19 \pm 1,54$; а у 18 років перебувала у відносній відповідності. У подальших роках у поодиноких досліджених пацієнтів це співвідношення коливається як у бік зменшення, так і в бік збільшення [7].

У групу обстежених жінок із двобічним незрощенням верхньої губи та піднебіння увійшло 15 пацієнтів віком від 8 до 32 років. Статистично опрацьовано тільки величини розмірів ширини зубного ряду верхньої щелепи пацієнтів 12, 15 та 16 років, усі інші вікові групи представлені поодинокими хворими. У двох спостереженнях 8 та 9 років ширина зубного ряду на рівні $4 \mid 4$ зубів була більшою за норму; в 11 років спостерігалося зменшення ширини зубного ряду на рівні $4 \mid 4$ зубів: $33,84 \pm 0,56$ проти норми $35,71 \pm 2,42$; у 15 ро- ків зменшення ширини на цьому рівні стало ще більшим: $32,76 \pm 2,65$ проти норми $38,88 \pm 3,94$; фактична ширина зубного ряду на рівні $6 \mid 6$ зубів у 12 та 15 років відповідає ширині нормального зубного ряду в межах статистичної похибки, проте в 16 років стає ширшою за норму $(53,67 \pm 2,36$ проти норми 44,62 $\pm 1,08)$.

Отже, для динаміки формування деформацій зубного ряду в пацієнтів із двобічним ПНВГП після операцій характерним є звуження зубного ряду верхньої щелепи на рівні $4 \mid 4$ зубів порівняно 3 нормою, починаючи з 9 років, зі збереженням такого звуження у наступні вікові періоди [6]. Ширина зубного ряду на рівні $6 \mid 6$ зубів у всі вікові періоди перебуває у відносній рівновазі з шириною нормального зубного ряду з деякими відхиленнями або у бік незначного звуження або незначного розширення [12]. 
فำ

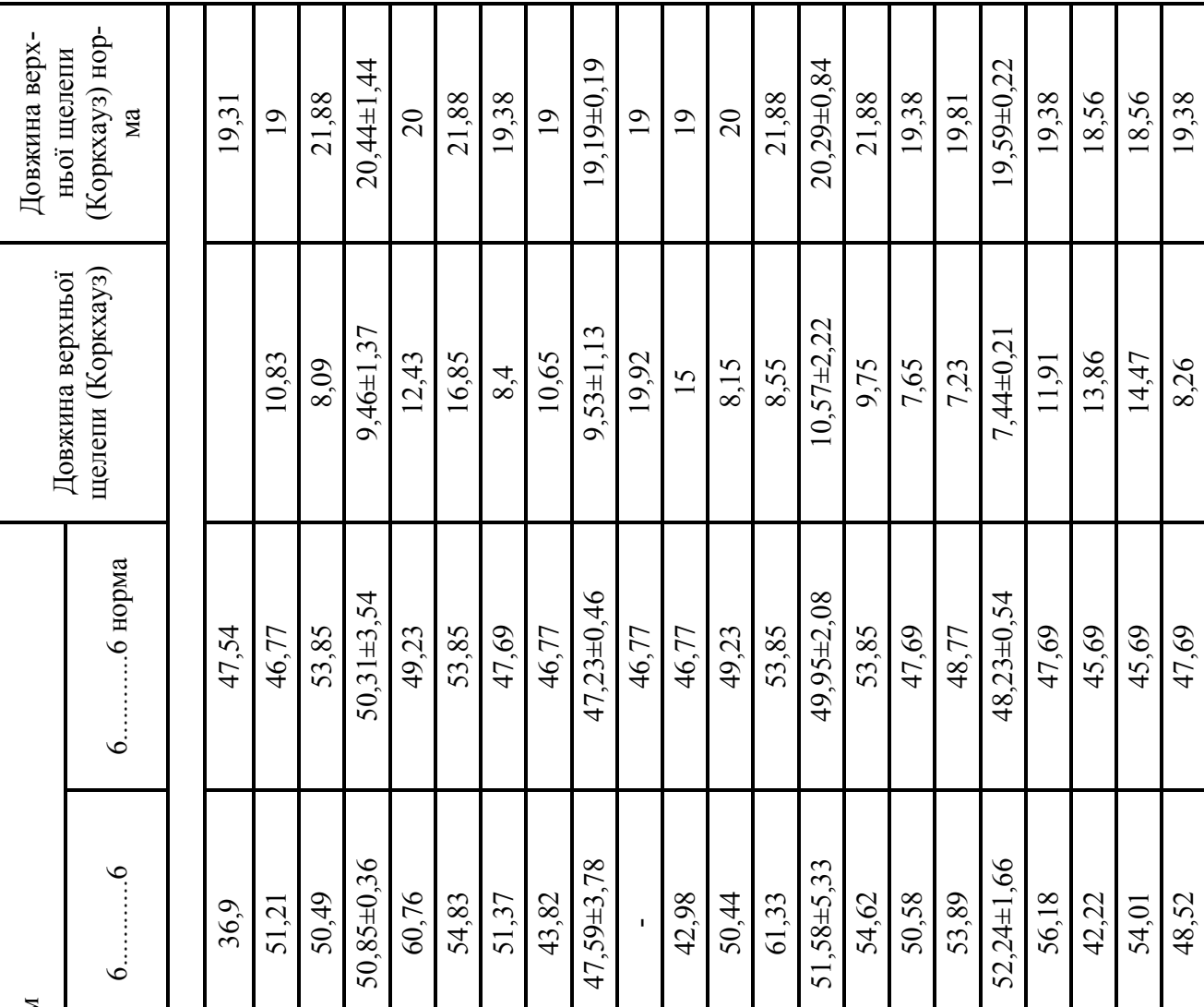

总

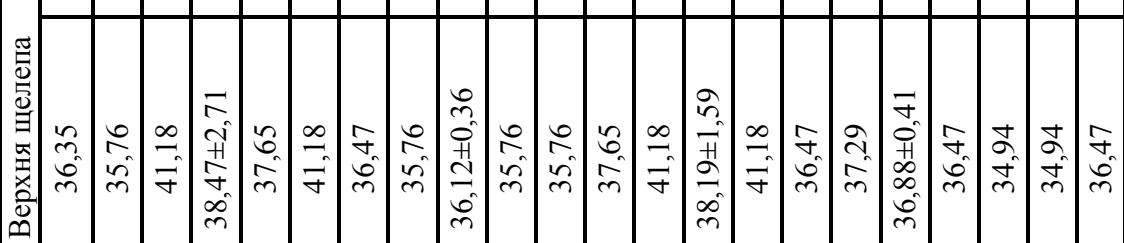

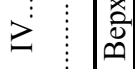

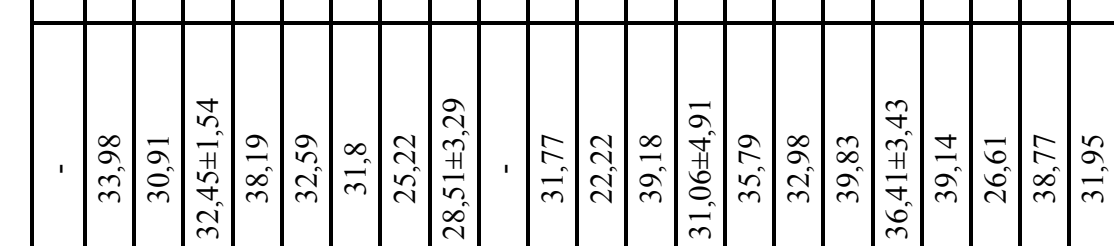

$\geq+$

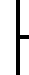

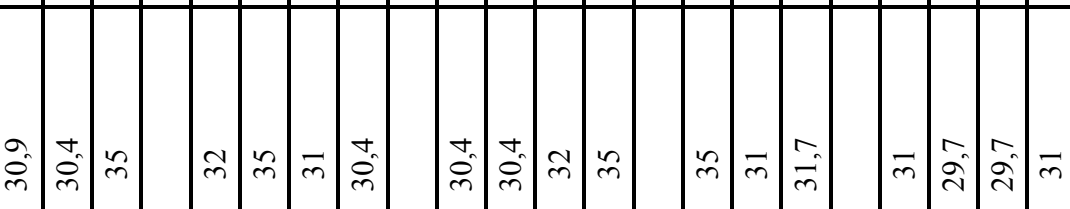

色

送

它

要总

魚菑氙

iे

$m \ddot{m} \vec{m} \dot{\infty}$

केल m

$m \vec{m}$

ते के

岕.苗

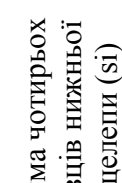

恣兹

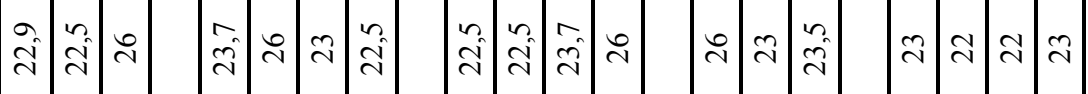

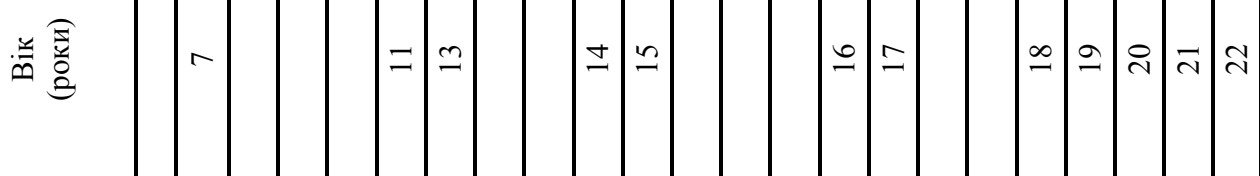




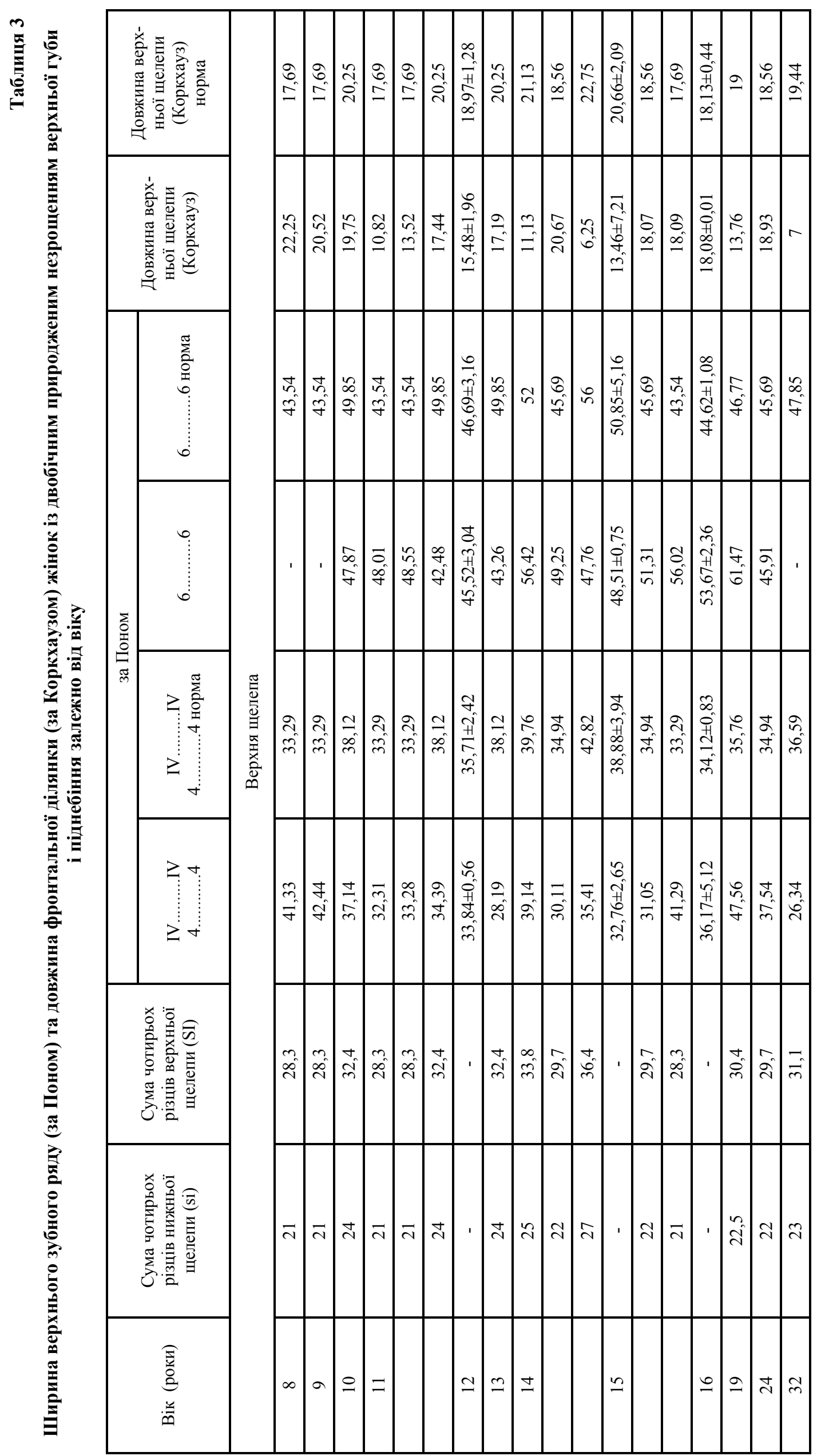




\section{Висновки}

1. Для двобічних наскрізних незрощень верхньої губи та піднебіння, яким були зроблені операції, характерним $є$ двобічне, майже рівномірне звуження верхньої щелепи і зменшення довжини переднього відрізка верхньої щелепи.

2. Виявлені особливості деформацій зубного ряду верхньої щелепи та динаміка їх формування повинні бути враховані при наданні ортодонтичної допомоги цим хворим та виборі відповідних ортопедичних конструкцій при їх подальшому протезуванні.

Перспективи подальших досліджень. Вивчити скелетні деформації верхньої та нижньої щелеп пацієнтів із ПНВГП після операційних втручань, обгрунтувати та опрацювати оптимальний алгоритм ортопедичного лікування в період формування постійного прикусу.

\section{Література}

1. Брашкин А.П. Распространенность врождённой расщелины верхней губы и неба у детей / А.П. Брашкин, С.П. Ярова // Укр. стоматол. альманах. - 2003. - № 5. C. 44-46.

2. Гулюк А.Г. Антропометрические особенности верхней челюсти у детей с врождёнными двусторонними сочетанными расщелинами верхней губы, альвеолярного отростка и нёба в предоперационном периоде и отдаленные сроки после поэтапного восстановления верхней губы / А.Г. Гулюк, В.Г. Крыкляс, Н.Б. Дмитриева // Дентальные технологии. - 2006. - № 3-6 (28-31). - С. 25-30.

3. Макєєв В.Ф. Аналіз оперативних втручань у хворих з природженими незрощеннями верхньої губи і піднебіння / В.Ф. Макєєв, Г.В. Олійник, Ю.Ю. Олійник // Укр. стоматол. альманах. - 2011. - № 3. - С. 30-33.

4. Олійник Г.В. Морфофункціональні особливості деформацій зубощелепної системи у хворих з вродженими незрощеннями верхньої губи і піднебіння та методи їх лікування в постійному прикусі: автореф. дис. на здобуття наук. ступеня канд. мед. наук : спец. 14.01.22 „Стоматологія” / Г.В. Олійник. - Львів, 2012. - 19 с.

5. Рягузова Е.Н. Морфологическое состояние зубных рядов у детей 12-15 лет с врождённой односторонней и двусторонней расщелиной верхней губы, альвеолярного отростка твердого и мягкого неба. Комплексное лечение хирурга и ортодонта: автореф. дис. на соискание учён. степени канд. мед. наук : спец. 14.00.21 „Стоматология” / Е.Н. Рягузова. - М., 2006. - 25 с.

6. Хорошилкина Ф.Я. Ортодонтия. Дефекты зубов, зубных рядов, аномалии прикуса, морфофункциональные нарушения в челюстно-лицевой области и их комплексное лечение: учебн. пособие / Ф.Я. Хорошилкина. М.: Мед информ. агенство, 2006. - 544 с.

7. Heliövaara A. Dental aches in six-year-old children with operated and unoperated submucous cleft palate and isolated cleft palate / A. Heliövaara, J. Rautio // Acta Odontol. Scand. - 2005. - Vol. 63, № 2. - P. 123-126.

8. Korkhaus G.G. Handbuch der Zahnheilkunde Bd. IV. Gebiss-, Kiefer- und Gesichtsorthopadie / G.G. Korkhaus // Bergmann, München. - 1939. - 1184 s.

9. Murtazaev S.S. Anthropometrical Parameters of the Orthognathic Bite in People of Uzbek Nationality / S.S. Murtazaev, I.E. Pak; S. Murtazaev // International Journal of Biomedicine. - 2015. - Vol. 5, № 1. - P. 35-37.

10. Pont A. Der Zahnindex in der Orthodontie / A. Pont // Z Zahnartl. Orthop. - 1909. - № 3. - P. 306-312.

11. The EUROCAT network: organization and processes. Birth Defects Research / P. Boyd., M. Haeusler, I. Barisic [et al.] // Clinical and Molecular Teratology (Part A). 2011. - Vol. 91. - P. S2-S15. - Available at : http:// www.eurocat-network.eu

12. The Maxillary Arch and its Relationship to Cephalometric Landmarks of Selected Malay Ethnic Group / K.M. Thu, T. Winn, N. Abdullah [et al.] // Malays J. Med. Sci. 2005. - Vol. 12, № 1. - P. 29-38.

\section{ОСОБЕННОСТИ ФОРМИРОВАНИЯ И ДИНАМИКА РАЗВИТИЯ ЗУБНОГО РЯДА ВЕРХНЕЙ ЧЕЛЮСТИ У ПАЦИЕНТОВ С ДВУСТОРОННИМИ ВРОЖДЕННЫМИ СКВОЗНЫМИ НЕСРАЩЕНИЯМИ ВЕРХНЕЙ ГУБЫ И НЕБА ПОСЛЕ ОПЕРАТИВНЫХ ВМЕШАТЕЛЬСТВ}

\section{А.Ю. Олийник}

Резюме. Проведен анализ 33 диагностических контрольных моделей в оперированных пациентов со сквозными двусторонними врожденными несращениями верхней губы и неба, определены ширина зубного ряда верхней челюсти и длина фронтального участка верхней челюсти и произведено сравнение их с нормой. Выявлены определенные характерные особенности деформаций зубного ряда верхней челюсти и динамика их формирования, которые обязательно должны учитываться при оказании ортодонтической помощи этим больным и последующем выборе соответствующих ортопедических конструкций для их адекватного протезирования.

Ключевые слова: врожденные несращения неба, деформации верхних зубных рядов.

\section{PECULIARITIES OF THE FORMATION AND DYNAMICS OF UPPER JAW DENTITION IN PATIENTS WITH BILATERAL CONGENITAL CLEFT LIP AND PALATE AFTER SURGERY}

\section{A.Y. Oliynyk}

Abstract. The analysis of 33 diagnostic patient models with bilateral transverse congenital clefts of the upper lip and palate has been done according to the age and sex peculiarities. The maxillary dentition width was compared to the normal state and the length of the upper jaw frontal area. We detected features of formation of deformations of the upper jaw dental row and their dynamics in patients with bilateral transverse congenital cleft of upper lip and palate should be considered in providing orthodontic care to these patients and choosing the right construction for their further orthopedic treatment.

Key words: congenital bilateral clefts, deformities of the upper dental row.

Danylo Halytsky National Medical University (Lviv)

Рецензент - проф. О.Б. Бєліков

(C) А.Ю. Олійник , 2015
Buk. Med. Herald. - 2015. - Vol. 19, № 4 (76). - P. 126-131 